\title{
Implementasi Instrumen Penilaian Berbasis Macromedia Flash dalam Evaluasi Pembelajaran Volume Kubus dan Balok di Kelas V SDN Depok 01
}

\author{
Mushthofiyah \\ PGSD FKIP UNISSULA \\ e-mail: mushthofiyah@gmail.com
}

\begin{abstract}
This research is motivated by the habit of implementing learning evaluation using classical assessment instruments at Depok 01 Elementary School, Kandeman District, Batang Regency, Central Java. The research focuses on implementing the macromedia flash-based assessment instrument in evaluating the volume of cube and block learning and looking for the results of the implementation of the macromedia flash-based assessment instrument. The aim of the study is to describe the implementation of the implementation and provide knowledge of the results of the implementation of the macromedia flash-based assessment instrument in learning evaluation ofvolume of cubes and blocks. The research design was descriptive qualitative. The data werecollected by observing the implementation of the evaluation of learning volume cubes and blocks using a macromedia flash based assessment instrument carried out by primary data sources, namely teachers and grade $V$ students, whom were interviewed, and documented in the form of pictures / photos and field notes. The validity of the research data used the credibility test (internal validity), transferability test (external validity), and dependability test (objectivity). The results showed that the implementation of macromedia flash-based assessment instrument in evaluating the volume of cubes and blocks in class V SDN Depok 01 went very well. It macromedia flashresulted in poor compliance with the requirements of a good evaluation tool. Various opinions from the teachers are in line with the existing theories. macromedia flashThe results of the implementation can be seen from the aspects of the teacher, students, and school according to the social situation of the research.
\end{abstract}

Keywords: Macromedia Flash Based Assessment Instruments, Evaluation of Learning Cubes and Beams

Abstrak. Penelitian dilatarbelakangi dari adanya kebiasaan pelaksanaan evaluasi pembelajaran menggunakan instrumen penilaian klasik di Sekolah Dasar Negeri Depok 01 Kecamatan Kandeman, Kabupaten Batang, Jawa Tengah. Penelitian fokus melaksanakan implementasi instrumen penilaian berbasis macromedia flash dalam evaluasi pembelajaran volume kubus dan balok serta mencari hasil implementasi instrumen penilaian berbasis macromedia flash di SDN Depok 01. Tujuan dari penelitian adalah mendeskripsikan pelaksanaan implementasi dan memberi pengetahuan hasil implementasi instrumen penilaian berbasis macromedia flash dalam evaluasi pembelajaran volume kubus dan balok di SDN Depok 01. Desain penelitian merupakan deskriptif kualitatf yaitu penelitian menggunakan metode kualitatif yang disajikan secara deskriptif. Pengumpulan data dilakukan dengan observasi pelaksanaan evaluasi pembelajaran volume kubus dan balok menggunakan instrumen penilaian berbasis macromedia flash yang dilakukan oleh sumber data primer yaitu guru dan siswa kelas $V$, wawancara dengan sumber data, lalu didokumentasikan dalam bentuk gambar/foto dan catatan lapangan. Keabsahan data penelitian menggunakan uji credibility (validitas internal), uji 
transferability (validitas eksternal), dan uji dependability (obyektivitas). Hasil penelitian menunjukkan bahwa pelaksanaaan implementasi instrumen penilaian berbasis macromedia flash dalam evaluasi pemebelajaran volume kubus dan balok di kelas V SDN Depok 01 berjalan sangat baik. Dalam mengimplementasikan instrumen penilaian berbasis macromedia flash pembelajaran volume kubus dan balok di SDN Depok 01 berakibat kurang baik dalam memenuhi syarat alat evaluasi yang baik. Beragam pendapat dari guru kelas V SDN Depok 01 sesuai dengan teori mengenai pelaksanaan implementasi instrumen penilaian berbasis macromedia flash dalam evaluasi pembelajaran volume kubus dan balok. Hasil implementasi dapat diketahui berdasarkan aspek dari guru, siswa, dan sekolah sesuai situasi sosial penelitian.

Kata kunci: Instrumen Penilaian Berbasis Macromedia Flash, Evaluasi Pembelajaran Volume Kubus dan Balok

\section{PENDAHULUAN}

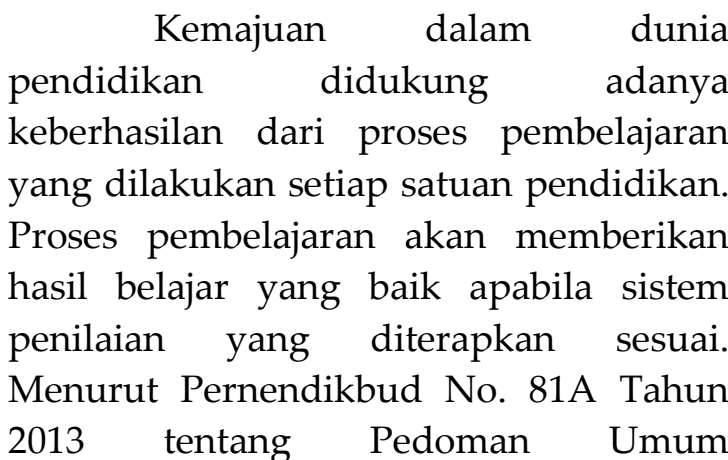
Implementasi Kurikulum 2013, penilaian merupakan serangkaian kegiatan untuk memperoleh, menganalisis, dan menafsirkan data tentang proses dan hasil belajar peserta didik yang dilakukan secara sistematis dan berkesinambungan, sehingga menjadi informasi yang bermakna dalam pengambilan keputusan. Peraturan tersebut menunjukkan bahwa setiap kurikulum mempunyai pedoman dalam implementasinya masing-masing. Berbeda dari kurikulum 2006, Peraturan kurikulum 2013 tersebut menjadi acuan dasar penerapan sistem penilaian yang akan digunakan pendidik untuk peserta didiknya.

Praktik penilaian yang terintegrasi dalam proses belajar-mengajar memberikan dampak yang signifikan terhadap peningkatan hasil belajar matematis siswa (Balan, 2010; Purnomo,
2015). Pernyataan tersebut menggambarkan dalam sebuah pembelajaran, bahwa siswa akan lebih terlatih dalam memecahkan masalah jika diberikan suatu persoalan yang berkaitan dengan materi yang dipelajarinya. Kebiasaan siswa dalam memecahkan permasalahan terkait materi yang dipelajarinya tersebut akan membawanya menjadi pribadi yang pandai menentukan keputusan yang tepat. Keputusan berdasarkan latihanlatihan yang diberikan guru tidak bisa diganti dengan jawaban lain karena hasil yang ditemukan merupakan sebuah kepastian yang tidak dapat dirubah. Maka diperlukan penilaian yang terstruktur untuk menjadikan siswa yang pandai dalam menentukan keputusan memilih jawaban yang tepat.

Dari beberapa uraian di atas, dapat disimpulkan bagaimana pentingnya penilaian dilakukan dalam evaluasi pembelajaran. Menyadari kesempulan tersebut, inovasi pembuatan instrumen penilaian dalam evaluasi pembelajaran perlu dilakukan, sebagaimana hasil analisis yang dilakukan oleh Aziz, Kustiono, dan Lestari (2019) bahwa: 
assessment instruments in learning macromedia flash based elementary school mathematics trhough the calculation of validity obtained mean square 0.956 and declared valid, as well as through the reliability test ebel obtained 0.414 so that it was declared reliable, so the needs analysis was declared valid and reliable the development of cube and beam volume instruments in Macromedia flash-based elementary mathematics learning is urgently needed.

Dari hasil analisis di atas, pengimplementasian inovasi instrumen penilaian berbasis macromedia flash diharapkan dapat memberikan manfaat atau alternatif lain dalam evaluasi pembelajaran di Sekolah Dasar Negeri Depok 01.

Berdasarkan observasi kunjungan pertama di SDN Depok 01 pada tanggal 9 Desember 2019, diketahui hasil wawancara bersama guru kelas $\mathrm{V}$ bahwa di Kelas V SDN Depok 01 belum pernah menerapkan instrumen penilaian berbasis Macromedia flash dalam evaluasi pembelajaran volume kubus dan balok. Dari hasil pegetahuan tersebut, ketersediaan Kepala Sekolah atau pihak dari SDN Depok 01 termasuk Guru wali kelas $\mathrm{V}$ dalam memberikan izin penelitian menjadi awal skripsi ini disusun dengan judul Implementasi Instrumen Penilaian Berbasis Macromedia flash Dalam Evaluasi Pembelajaran Volume Kubus dan Balok di Kelas V SDN Depok 01.

Tujuan penelitian adalah untuk mendeskripsikan pelaksanaan evaluasi pembelajaran volume kubus dan balok menggunakan instrumen penilaian berbasis Macromedia flash di kelas V SDN Depok 01 dan untuk memberi pengetahuan hasil implementasi instrumen penilaian berbasis Macromedia flash dalam evaluasi pembelajaran volume kubus dan balok di kelas V SDN Depok 01.

Penelitian yang dilakukan oleh Andrijati (2014) tentang penerapan media pembelajaran inovatif dalam pembelajaran matematika sekolah dasar di PGSD UPP Tegal merupakan salah satu penelitian yang relevan. Penelitian tersebut mengkaji penelitian skripsi mahasiswa PGSD mengenai penerapan media inovatif dalam pembelajaran matematika sekolah dasar. Adapun salah satu judul dari skripsi tersebut adalah Peningkatan Aktivitas dan Hasil Belajar Siswa Kelas IV pada Materi Bangun Datar melalui Penggunaan Macromedia flash di Sekolah Dasar Negeri Tegalsari 4 Tegal Oleh Nurman Tri Anggoro. Hasil dari penelitian yang dikaji diantaranya: Perolehan skor performansi guru dalam pembelajaran pada siklus I dan siklus II menunjukkan bahwa guru telah menerapkan macromedia flash dalam pembejaran bangun datar dengan baik dan telah terjadi peningkatan skor sebesar 8,48; Telah terjadi peningkatan keterlibatan siswa dalam penerapan macromedia flash dalam pembelajaran bangun datar di kelas IV dari siklus I ke siklus II sebesar $11,71 \%$; dan telah terjadi peningkatan dari siklus I ke siklus II baik skor rata-rata kelas maupun presentase tuntas klasikalnya.

\section{METODE}

Desain penelitian ini merupakan penelitian metode kualitatif. Dalam menggambarkan kondisi obyek yang alamiah akan disajikan secara deskriptif tentang pelaksanaan implementasi instrumen penilaian berbasis macromedia flash dalam evaluasi pembelajaran volume kubus dan balok. Penelitian dilakukan di kelas V SD Negeri Depok 01 yang terletak 
di Desa Depok, Dukuh Tegalrejo, Kecamatan Kandeman, Kabupaten Batang, Jawa Tengah.

Sumber data dalam penelitian terdiri dari tempat (place), pelaku (actors), dan aktivitas (activity) sebagaimana dikemukakan Spradley (Sugiyono, 2017) bahwa "Dalam penelitian kualitatif tidak menggunakan istilah populasi, tetapi dinamakan 'social situation' atau situasi sosial yang terdiri atas tiga elemen yaitu: tempat (place), pelaku (actors), dan aktivitas (activity) yang berinteraksi secara sinergis". Pengumpulan data dalam penelitian menggunakan sumber primer yaitu Siswa kelas V dan Guru walinya.

Penelitian menggunakan cara gabungan/triangulasi yaitu dengan melakukan observasi, wawancara, dan dokumentasi. Observasi dilakukan dengan menyatakan secara langsung kepada sumber data yaitu Guru wali kelas $\mathrm{V}$ dan siswa kelas $\mathrm{V}$, bahwa penelitian akan dilakukan di Kelas V SDN Depok 01. Wawancara terstruktur digunakan bersama guru kelas dan tak berstruktur dilakukan bersama siswa. Dokumen dalam penelitian ini merupakan hasil observasi guru dan siswa, hasil wawancara guru dan siswa, dan gambar (foto-foto selama penelitian berlangsung).

Penelitian ini menggunakan analisis data model Spradley (1980). Tahapan analisis data yang dilakukan dalam penelitian adalah analisis domain, analisis taksonomi, analisis komponensial, dan analisis tema kultural. Analisis domain dilakukan dengan memperoleh gambaran umum pelaksanaan evaluasi pembelajaran volume kubus dan balok yang mengimplementasikan instrumen penilaian berbasis macromedia flash. Analisis taksonomi dilakukan dengan menjabarkan lebih luas dan rinci gambaran pelaksanaan evaluasi belajar dengan mengamati sumber data yaitu Guru wali kelas V dan siswanya. Analisis komponensial dilakukan dengan mencari informasi melalui wawancara mengenai pelaksanaan implementasi instrumen penilaian berbasis macromedia flash dalam evaluasi pembelajaran volume kubus dan balok kepada guru kelas dan siswa. Analisis tema kultural dilakukan dengan mencari hubungan keseluruhan pelaksanaan implementasi instrumen penilaian macromedia flash dalam evaluasi pembelajran volume kubus dan balok serta menjabarkan hasil implementasi instrumen penilaian berbasis macromedia flash, sehingga dapat menyatakan ke dalam judul penelitian.

Pengujian keabsahan data dalam penelitian ini menggunakan uji credibility, transferability, dan dependability. Dalam uji credibility (validitas internal) menggunakan bahan referensi untuk menguji kredibilitas data penelitian. Dalam hal ini, maka dalam pembuatan laporan, data-data yang diperoleh dari penelitian akan dilengkapi dengan fotofoto atau dokumen autentik. Dalam uji transferability (validitas eksternal), akan disajikan laporan dengan mendeskripsikan pelaksanaan dan hasil implementasi instrumen penilaian berbasis Macromedia flash dalam evaluasi pembelajaran volume kubus dan balok di Kelas V SDN Depok 01 dengan rinci, jelas, dan sistematis, sehingga dapat mudah dipahami pembaca serta memungkinkan untuk diaplikasikan di tempat lain. Dalam uji dependability (reliabilitas), dilakukan oleh auditor yang independen atau pembimbing untuk mengaudit keseluruhan aktivitas peneliti dalam melakukan penelitian, mulai dari bagaimana peneliti menentukan masalah/fokus, memasuki lapangan, menentukan sumber data, melakukan 
analisis data, melakukan uji keabsahan data, sampai membuat kesimpulan harus ditunjukkan oleh peneliti. Dalam hal ini, maka uji dependability (realitas) akan dilakukan oleh dosen pembimbing dibuktikan dengan paraf dosen pembimbing dalam kartu bimbingan yang terdapat pada buku bimbingan skripsi program studi pendidikan guru sekolah dasar Unissula 2019.

\section{HASIL DAN PEMBAHASAN}

\section{Pelaksanaan Evaluasi Pembelajaran} Volume Kubus dan Balok Menggunakan Instrumen Penilaian Berbasis Macromedia flash di Kelas V SDN Depok 01

Implementasi instrumen penilaian berbasis macromedia flash dalam evaluasi pembelajaran volume kubus dan balok di Kelas V SD Negeri Depok 01 dilaksanakan hari senin, 16 Maret 2020. Dalam pelaksanaannya terdapat banyak keterbatasan untuk melakukan penelitian dikarenakan pada hari senin, 16 Maret 2020 adalah hari pertama diberlakukannya sistem pembelajaran daring di masa pandemi bagi seluruh sekolah di Kabupaten Batang termasuk Sekolah Dasar Negeri Depok 01. Penelitian dilaksanakan sekitar jam 08.15 setelah seluruh siswa selesai melaksanakan apel atau mendapat sosialisai dari sekolah terkait peliburan sekolah karena adanya wabah virus korona yang melanda negeri. Dalam pelaksanaannya, evaluasi dibuka oleh guru kelas V SDN Depok 01 yang menyampaikan kepada siswa bahwa akan dilaksanakan penelitian yaitu evaluasi pembelajaran volume kubus dan balok menggunakan instrumen penilaian berbasis macromedia flash.
Kemudian setelah guru selesai membuka kelas, peneliti juga izin menyapa siswa. Peneliti menyampaikan permintaan maaf terkait penundaan waktu kepulangan siswa karena adanya penelitian sekaligus menanyakan kesiapan dan memberi semangat siswa dalam melakukan evaluasi pembelajaran volume kubus dan balok.

Setelah semua siswa siap melaksanakan evaluasi pembelajaran volume kubus dan balok menggunakan instrumen penilaian macromedia flash, siswa dipanggil satu persatu sesuai urut absen untuk mulai mengerjakan evaluasi yang telah disiapkan di depan kelas.

Selama proses pelaksanaan evaluasi pembelajaran, waktu menjadi kendala dikarenakan terdapat 45 siswa yang harus mengerjakan evaluasi menggunakan instrumen penilaian berbasis macromedia flash. Maka dari itu, dalam penelitiannya peneliti mengajak teman sejawat untuk ikut andil dalam penelitian, yaitu menyediakan 1 laptop lagi dan mencatat hasil nilai atau score yang diperoleh ketika siswa selesai mengerjakan evaluasi. Dari hasil kesepakatan antara guru kelas dan peneliti menggunakan 2 laptop untuk mempersingkat waktu, semua siswa dibagi menjadi 2 bagian. Presensi 1-24 melaksanakan evaluasi pembelajaran dengan pengawasan guru kelas, kemudian presensi 25-48 melaksanakan evaluasi pembelajaran dengan pengawasan teman peneliti.

$$
\text { Ketika proses evaluasi }
$$

pembelajaran berlangsung, peneliti berada di belakang kelas dalam menjalankan pengamatan terhadap guru kelas serta siswanya, sekaligus 
melakukan wawancara bersama siswa yang telah menyelesaikan evaluasi pembelajaran volume kubus dan balok. Berikut merupakan hasil penelitian yang diperoleh selama pelaksanaan evaluasi pembelajaran volume kubus dan balok menggunakan instrumen penilian berbasis macromedia flash berlangsung.

a) Hasil observasi guru

Dalam mengamati guru saat melaksanakan evaluasi pembelajaran volume kubus dan balok menggunakan instrumen penilaian berbasis macromedia flash, berikut merupakan hasil observasi guru selama evaluasi pembelajaran volume kubus dan balok menggunakan instrumen penilaian berbasis macromedia flash berlangsung.

\section{Tabel 1. Hasil Observasi Guru}

\begin{tabular}{|c|c|c|c|c|c|}
\hline \multirow{2}{*}{ No } & \multirow{2}{*}{ Aspek Pengamatan } & \multicolumn{4}{|c|}{ Penilaian } \\
\hline & & 1 & 2 & 3 & 4 \\
\hline 1 & $\begin{array}{l}\text { Dapat menyampaikan kegiatan } \\
\text { penilaian menggunakan instrumen } \\
\text { berbasis macromedia flash yang akan } \\
\text { dilaksanakan dengan jelas }\end{array}$ & & & & $\sqrt{ }$ \\
\hline 2 & $\begin{array}{l}\text { Tidak melakukan kegiatan- } \\
\text { kegiatan di luar kegiatan evaluasi } \\
\text { belajar, misalnya sibuk dengan } \\
\text { urusan lain. }\end{array}$ & & & & $\sqrt{ }$ \\
\hline 3 & $\begin{array}{l}\text { Menikmati mengawasi siswa } \\
\text { dalam mengisi instrumen penilaian } \\
\text { berbasis macromedia flash. }\end{array}$ & & & & $\sqrt{ }$ \\
\hline 4 & $\begin{array}{l}\text { Menyesal karena instrumen } \\
\text { penilaian yang digunakan lebih } \\
\text { rumit dibanding instrumen } \\
\text { penilaian klasik.. }\end{array}$ & & $\sqrt{ }$ & & \\
\hline 5 & $\begin{array}{l}\text { Memberikan sikap terbuka kepada } \\
\text { siswa untuk bertanya tentang } \\
\text { sistem penilaian } \\
\text { macromedia flash. }\end{array}$ & & & & $\sqrt{ }$ \\
\hline 6 & $\begin{array}{l}\text { Mampu menjelaskan sistem } \\
\text { penilaian berbasis macromedia flash } \\
\text { kepada siswa yang betanya. }\end{array}$ & & & & $\sqrt{ }$ \\
\hline 7 & $\begin{array}{l}\text { Dapat memantau kegiatan evaluasi } \\
\text { siswa dengan baik. }\end{array}$ & & & & $\sqrt{ }$ \\
\hline 8 & $\begin{array}{l}\text { Mendapatkan data nilai dari semua } \\
\text { siswa. }\end{array}$ & & & & $\sqrt{ }$ \\
\hline
\end{tabular}

Jumlah Skor

30

b) Hasil observasi siswa

Dalam mengamati siswa saat melaksanakan evaluasi pembelajaran volume kubus dan balok menggunakan instrumen penilaian berbasis macromedia flash, berikut merupakan hasil observasi siswa selama evaluasi pembelajaran volume kubus dan balok menggunakan instrumen penilaian berbasis macromedia flash berlangsung.

Tabel 2. Hasil Observasi Siswa

\begin{tabular}{|c|c|c|c|c|c|}
\hline \multirow{2}{*}{ No } & \multirow{2}{*}{ Aspek Pengamatan } & \multicolumn{4}{|c|}{ Penilaian } \\
\hline & & 1 & 2 & 3 & 4 \\
\hline 1 & $\begin{array}{l}\text { Mengerjakan soal-soal yang ada } \\
\text { pada instrumen penilaian berbasis } \\
\text { macromedia flash. }\end{array}$ & & & & $\sqrt{ }$ \\
\hline 2 & $\begin{array}{l}\text { Tidak melakukan kegiatan- } \\
\text { kegiatan di luar kegiatan evaluasi } \\
\text { belajar, misalnya mengobrol atau } \\
\text { bermain sendiri. }\end{array}$ & & $\sqrt{ }$ & & \\
\hline 3 & $\begin{array}{l}\text { Mengeluh karena instrumen } \\
\text { penilaian yang digunakan } \\
\text { membingungkan. }\end{array}$ & & $\sqrt{ }$ & & \\
\hline 4 & $\begin{array}{l}\text { Menikmati mengerjakan soal-soal } \\
\text { dalam instrumen penilaian } \\
\text { berbasis macromedia flash. }\end{array}$ & & & & $\sqrt{ }$ \\
\hline 5 & $\begin{array}{l}\text { Tidak banyak bertanya (paham) } \\
\text { tentang cara menggunakan } \\
\text { instrumen penilaian berbasis } \\
\text { macromedia flash. }\end{array}$ & & & & $\sqrt{ }$ \\
\hline 6 & $\begin{array}{l}\text { Mengikuti petunjuk yang ada } \\
\text { dalam instrumen penilaian } \\
\text { berbasis macromedia flash. }\end{array}$ & & & & $\sqrt{ }$ \\
\hline 7 & $\begin{array}{l}\text { Dapat menjawab soal dalam } \\
\text { instrumen penilaian berbasis } \\
\text { macromedia flash. }\end{array}$ & & & & $\sqrt{ }$ \\
\hline & Jumlah Skor & & & & \\
\hline
\end{tabular}

c) Hasil wawancara siswa

Wawancara bersama siswa dilakukan setelah siswa menyelesaikan evaluasi pembelajaran volume kubus dan balok menggunakan instrumen penilaian berbasis macromedia flash. Dalam menyajikan deskripsi kegiatan 
wawancaranya, 45 siswa sebagai narasumber dilambangkan dengan inisial atau huruf awal nama masingmasing siswa. Berikut merupakan inisial 45 siswa kelas V SDN Depok 01 diantaranya, AW, AHJ, AHF, AS, ADP, DKAK, IA, IDM, IAN, IK, IN, MII, AY, AL, AWs, DF, MKM, MZ, MBS, MF, MR, MA, NEO, RPE, SM, $\mathrm{TZH}, \mathrm{ZS} . \mathrm{AF}, \mathrm{ATW}, \mathrm{AZ}, \mathrm{BA}$, FIR, MKP, NU, NZA, R, AM, $\mathrm{BAD}, \mathrm{EA}, \mathrm{KPH}, \mathrm{LWP}, \mathrm{MAS}$, RR, RAP, dan KA.

d) Hasil Evaluasi Siswa

Dalam pelaksanaannya, evaluasi yang dikerjakan siswa pada laptop 1 merupakan siswa dengan presensi 1-24. Pencatatan hasil evaluasi dilakukan oleh guru. Selanjutnya evaluasi yang dikerjakan siswa pada laptop 2 merupakan siswa dengan presensi 25-48. Pencatatan hasil evaluasi dilakukan oleh teman sejawat peneliti.

e) Hasil wawancara guru

Kegiatan terakhir penelitian adalah wawancara bersama guru. Wawancara dilaksanakan ketika semua siswa dipulangkan atau telah meninggalkan ruang kelas.

2. Hasil Implementasi Instrumen Penilaian Berbasis Macromedia flash Dalam Evaluasi Pembelajaran Volume Kubus dan Balok

Berdasarkan dokumen catatan lapangan yang ada, berikut merupakan hasil implementasi instrumen penilaian berbasis macromedia flash dalam evaluasi pembelajaran volume kubus dan balok di Kelas V SDN Depok 01.

a. Aspek dari Guru

Dalam pengamatan diwaktu pelaksanaan evaluasi pembelajaran volume kubus dan balok menggunakan instrumen penilaian berbsis macromedia flash berlangsung, diketahui bahwa Guru mengarahkan kembali siswa untuk membuka materi dengan tujuan mengondisikan keadaan kelas agar tetap kondusif. Selain itu, cara lain dalam mengondisikan kelas, guru juga memberikan reward yang akan diberikan kepada 2 siswanya yang memperoleh skor tertinggi. Dalam pelaksanaannya, hasil evaluasi menunjukkan skor tertinggi diperoleh AM dan EA.

b. Aspek dari Siswa

Dalam pengamatan diwaktu pelaksanaan evaluasi pembelajaran volume kubus dan balok menggunakan instrumen penilaian berbsis macromedia flash berlangsung, beberapa siswa ditemukan dalam keadaan gerogi, belum belajar, dan menggunakan laptop untuk pertama kalinya dalam evaluasi pembelajaran volume kubus dan balok.

c. Aspek dari Sekolah

Dalam percakapan bersama guru kelas diwaktu palaksanaan evaluasi pembelajaran volume kubus dan balok menggunakan instrumen penilaian berbsis macromedia flash berlangsung, diketahui bahwa SD Negeri Depok 01 merupakan sekolah yang tidak ada mata pelajaran Mulok (Muatan Lokal) TIK, melainkan menggunakan Muatan Lokal Tata Boga. 


\section{PEMBAHASAN}

1. Pelaksanaan Evaluasi Pembelajaran Volume Kubus dan Balok Menggunakan Instrumen Penilaian Berbasis Macromedia flash di Kelas V SDN Depok 01

Pelaksanaan implementasi instrumen penilaian berbasis macromedia flash dalam evaluasi pembelajaran volume kubus dan balok di kelas V SDN Depok 01 menggunakan instrumen penelitian observasi guru dan siswa, wawancara guru dan siswa, dan nilai evaluasi siswa pembelajaran volume kubus dan balok.

\section{a. Hasil Observasi Guru}

Dalam penilaian terhadap aspek pengamatan yang dilakukan oleh guru, dihasilkan jumlah skor 30 . Berdasarkan petunjuk penskoran, perhitungan skor akhir menggunakan rumus sebagai berikut:

Skor akhir $=\frac{\text { Skor yang diperoleh }}{\text { Skor maksimal }} \mathrm{X} 4$

Keterangan:

- Skor maksimal $=8 \times 4=32$

Maka dalam pengamatannya, hasil skor akhir diperoleh sebagai berikut:

Skor akhir $=\frac{30}{32} \mathrm{X} 4$

$$
=3,75
$$

Sesuai Permendikbud No. 81A Tahun 2013, predikat penilaian diperoleh sebagai berikut:

Sangat Baik : apabila memperoleh skor : $3,33<$ skor $\leq$ 4,00
Baik : apabila memperoleh skor : $2,33<$ skor $\leq 3,33$

Cukup Baik : apabila memperoleh skor : 1,33< skor $\leq$ 2,33

Kurang Baik : apabila memperoleh skor : skor $\leq 1,33$

Berdasarkan skor akhir menunjukkan perolehan skor 3,75, maka predikat penilaian dalam observasi guru mengimplementasikan instrumen penilaian berbasis macromedia flash dalam evaluasi pembelajaran volume kubus dan balok adalah sangat baik.

b. Hasil Observasi Siswa

Dalam penilaian terhadap aspek pengamatan yang dilakukan oleh siswa, dihasilkan jumlah skor 24 . Berdasarkan petunjuk penskoran, perhitungan skor akhir menggunakan rumus sebagai berikut:

Skor akhir $=\frac{\text { Skor yang diperoleh }}{\text { Skor maksimal }} \mathrm{X} 4$

Keterangan:

- Skor maksimal $=7 \times 4=28$

Maka dalam
pengamatannya, hasil skor
akhir diperoleh sebagai berikut:

Skor akhir $=\frac{24}{28} \mathrm{X} 4$

$=3,4$

Sesuai Permendikbud No. 81A Tahun 2013, predikat penilaian diperoleh sebagai berikut: 


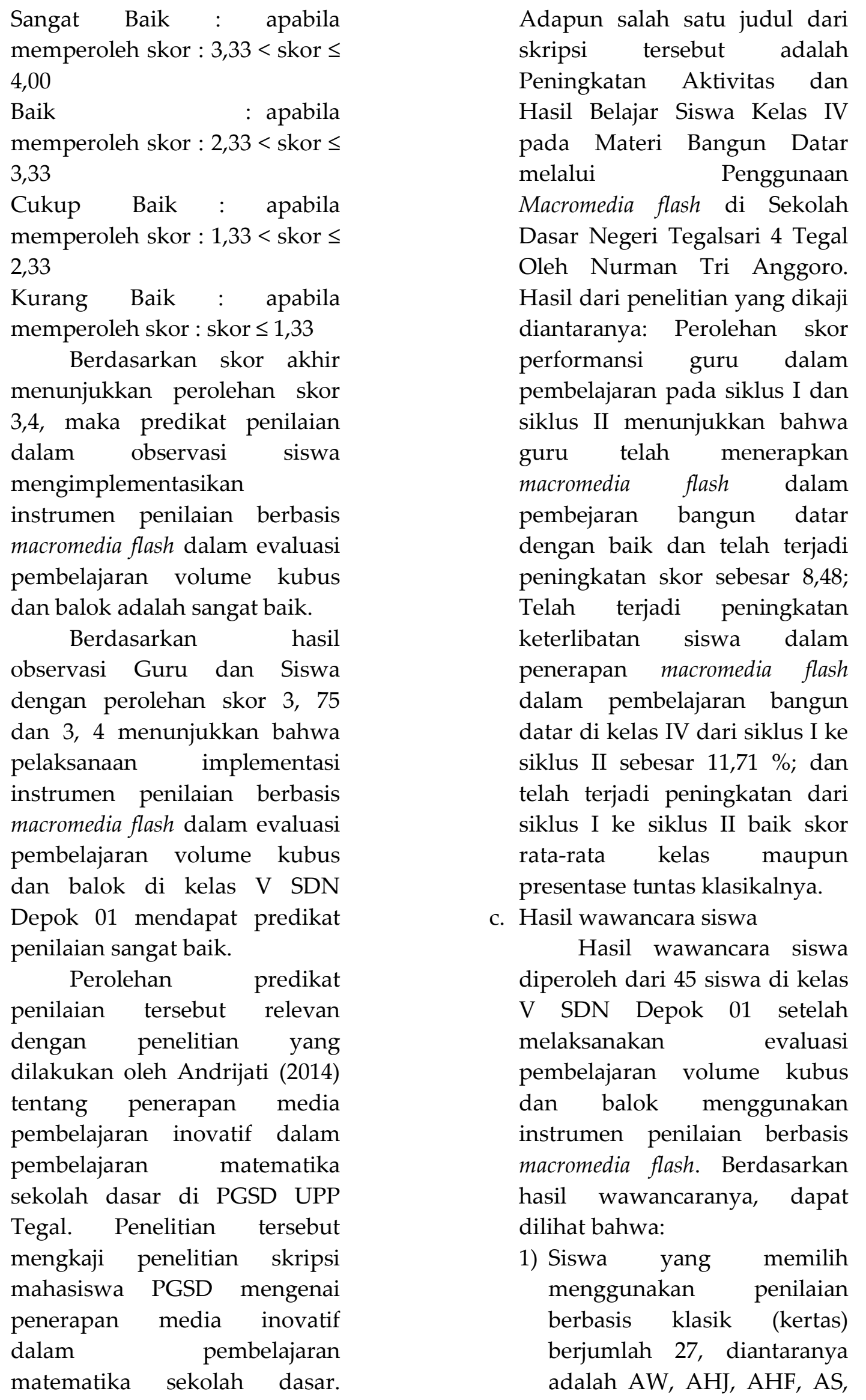


ADP, DKAK, IA, IDM, IAN, IK, IN, MII, AY, AL, AWs, DF, MKM, MZ, MBS, MF, MR, MA, NEO, RPE, SM, $\mathrm{TZH}$, dan ZS.

2) Siswa yang memilih menggunakan penilaian berbasis macromedia flash (laptop) berjumlah 18, diantaranya adalah $\mathrm{AF}$, ATW, AZ, BA, FIR, MKP, NU, NZA, R, AM, BAD, EA, $\mathrm{KPH}, \mathrm{LWP}, \mathrm{MAS}, \mathrm{RR}, \mathrm{RAP}$, dan KA.

Hasil wawancara di atas menunjukkan bahwa siswa yang memilih menggunakan penilaian berbasis klasik (kertas) berjumlah 27 dan siswa yang memilih menggunakan penilaian berbasis macromedia flash (laptop) berjumlah 18. Jumlah pemilihan instrumen penilaian evaluasi pembelajaran tersebut dipengaruhi dari beragam alasan masing-masing siswa di kelas V SDN Depok 01.

Beragam alasan siswa tersebut menunjukkan bahwa instrumen penilaian berbasis macromedia flash yang diterapkan dalam evaluasi pembelajaran kurang baik. Maka dari itu, implementasi instrumen penilaian tersebut berakibat kurang baik pula pada instrumen evaluasi dalam memenuhi syaratnya, sebagaiama Sanjaya (2008) mengatakan bahwa syaratsyarat alat evaluasi yang baik harus memenuhi berbagai syarat. Syarat tersebut diantaranya sebagai berikut:
[1] memberikan motivasi. Memberikan penilaian evaluasi diarahkan untuk meningkatkan motivasi belajar siswa melalui upaya pemahaman kekuatan dan kelemahan yang dimiliki baik oleh guru maupun siswa. [2] Validitas. Penilaian diarahkan bukan semata-mata untuk melengkapi syarat administrasi saja, tetapi untuk memperoleh informasi tentang ketercapaian kompetensi seperti yang terumuskan dalam kurikulum. [3] adil. Setiap siswa memiliki kesempatan yang sama dalam proses pembelajaran tanpa memandang perbedaan sosialekonomi, latar belakang budaya, dan kemampuan. [4] terbuka. Alat penilaian yang baik adalah alat penilaian yang dipahami baik oleh penilai maupun yang dinilai. [5] berkesinambungan. Penilaian tidak pernah mengenal waktu. [6] bermakna. Penilaian yang tersusun dan terarah akan memberikan makna kepada semua pihak, khususnya siswa untuk mengetahui posisi mereka dalam memperoleh kompetensi dan memahami kesulitan yang dihadapi dalam mencapai kompetensi. [7] menyeluruh. Kurikulum diarahkan untuk perkembangan siswa secara utuh, baik perkembangan afektif, kognitif, maupun psikomotorik. [8] edukatif. Penilaian kelas tidak semata-mata diarahkan untuk memperoleh gambaran kemampuan siswa dalam 
pencapaian kompetensi melalui angka, tetapi hasil penilaian juga harus memberikan umpan balik untuk memperbaiki proses pembelajaran, baik yang dilakukan oleh guru maupun siswa, sehingga hasil belajar lebih optimal.

d. Hasil Evaluasi Siswa

Hasil evaluasi siswa diperoleh dari skor akhir atau nilai kognitif yang didapatkan 45 siswa di kelas V SDN Depok 01 setelah melaksanakan evaluasi pembelajaran volume kubus dan balok.

1) Hasil Evaluasi Siswa pada Laptop 1

AW memperoleh skor 41,67, AF memperoleh skor 50, AHJ memperoleh skor 58,33, AHF memperoleh skor 33,33, AS memperoleh skor 16,67, ATW memperoleh skor $66,67, \mathrm{AZ}$ memperoleh skor 50, ADP memperoleh skor 41,67 , BA memperoleh skor 33,33, DKAK memperoleh skor 41,67, FIR memperoleh skor 50, IA memperoleh skor 33,33, IDM memperoleh skor 66,67, IAN memperoleh skor 50, IK memperoleh skor 33,33, IN memperoleh skor 50, MKP memperoleh skor 66,67, MII memperoleh skor 33,33, NU memperoleh skor 41,67, NZA memperoleh skor 50 , dan $\mathrm{R}$ memperoleh skor 66,67.

2) Hasil Evaluasi Siswa pada Laptop 2
AY memperoleh skor 41,67, AL memperoleh skor 41,67, AWs memperoleh skor 50, AM memperoleh skor 91,67, BAD memperoleh skor 58,33, DF memperoleh skor 33,33, EA memperoleh skor $75, \mathrm{KPH}$ memperoleh skor 66,67, LWP memperoleh skor 58,33, MKM memperoleh skor $58,33, \mathrm{MZ}$ memperoleh skor 16,67, MAS memperoleh skor 75, MBS memperoleh skor 33,33, MF memperoleh skor 58,33, MR memperoleh skor 58,33, MA memperoleh skor 58,33, NEO memperoleh skor 25, RR memperoleh skor 41,67, RAP memperoleh skor 50, RPE memperoleh skor 33,33, SM memperoleh skor 16,67 , TZH memperoleh skor 66,67, ZS memperoleh skor 33,33, dan KA memperoleh skor 50 .

Dari hasil perolehan skor yang diperoleh siswa kelas V SDN Depok 01 menunjukkan keakuratan penilaian dalam mengevaluasi hasil pembelajaran volume kubus dan balok. Hasil penilaian yang akurat tersebut menjadi bukti bahwa instrumen penilian berbasis macromedia flash diperlukan dalam evaluasi pembelajaran volume kubus dan balok di kelas V SDN Depok 01 sebagaimana Mashudi (2016) menyatakan bahwa "instrumen 
Jurnal Riset Pendidikan Dasar

Volume 2 Nomor 1, Maret 2021; DOI 10.30595/jrpd.v2i1.8803

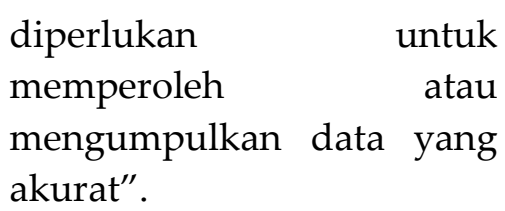

e. Hasil wawancara guru

Wawancara bersama guru kelas dilaksanakan setelah implementasi instrumen penilaian berbasis macromedia flash selesai dilaksanakan. Hasil wawancara menghasilkan beragam pendapat yang sesuai dengan teori mengenai pelaksanaan implementasi instrumen penilaian berbasis macromedia flash dalam evaluasi pembelajaran volume kubus dan balok.

1) Jika instrumen penilaian berbasis Macromedia flash diimplementasikan dalam evaluasi pembelajaran volume kubus dan balok, kondisi belajar dan mengajar menurut guru kelas adalah baik dan lebih antusias dilakukan siswa. Hal itu didukung dari pernyataan yang mengatakan bahwa "Penggunaan media berbasis flash yaitu macromedia flash 8 menambah antusias dan semangat siswa dalam mengikuti proses pembelajaran". (Nurjanah, Kusumadewi, Ulia, 2019).

2) Aziz, Kustiono, dan Lestari (2019), menyatakan bahwa Kurikulum 2013 berfokus pada IT (Information Technology), HOTS (Higher Order Thinking Skills), melek huruf, dan
PPK (Penguatan

Pendidikan Karakter). Selain itu (Bharti, 2017: 791) juga mengemukakan bahwa teknologi akan memberikan kontribusi yang cukup besar dan unik untuk pendidikan anakanak. Sejalan dengan hal tersebut, instrumen penilaian berbasis Macromedia flash merupakan instrumen berbasis teknologi. Pendapat guru kelas mengenai instrumen penilaian yang mengandalkan teknologi yaitu lebih menarik siswa karena gambarnya lebih aplikatif. Akan tetapi karena keterbatasan fasilitas (jumlah laptop) sehingga peserta didik kurang mampu memanfaatkan waktu. Pendapat tersebut menunjukkan guru kelas menjelaskan kelebihan mengandalkan macromedia flash dalam evaluasi pembelajaran. Sebagaimana kelebihan macromedia flash yang lebih menarik digunakan dalam pembelajaran tersebut, Edy (Hidayat, 2007) menjabarkan kelebihan lainnya yang dapat dijadikan instrumen penilaian atau media pembelajaran yaitu: [1] Animasi dan gambar konsisten dan fleksibel, karena tetap terlihat bagus 
pada ukuran jendela dan resolusi layar berapapun pada monitor pengguna. [2] Kualitas gambar terjaga. Hal ini disebabkan karena flash meggunakan teknologi vector graphics yang mendeskripsikan gambar memakai garis dan kurva, sehingga ukurannya dapat diubah sesuai dengan kebutuhan tanpa mengurangi atau mempengaruhi kualitas gambar. [3] Waktu loading (kecepatan gambar atau animasi muncul atau loading time) lebih cepat dibandingkan dengan pengolah animasi lainnya, seperti animated gifs dan java applet. [4] Mampu membuat website yang interaktif, karena pengguna (user) dapat menggunakan keyboard atau mouse untuk berpindah ke bagian lain dari halaman web atau movie, memindahkan objek, memasukkan informasi di form. [5] Mampu menganimasi grafis yang rumit dengan sangat cepat sehingga membuat animasi layar penuh bisa langsung disambungkan ke situs web. [6] Mampu secara otomatis mengerjakan sejumlah frame antara awal dan akhir sebuah urutan animasi, sehingga tidak membutuhkan waktu yang lama untuk membuat berbagai animasi. [7]
Mudah diintegrasikan dengan program macromedia yang lain, seperti Dreamwater, Fireforks, dan Authorware, karena tampilan dan tool yang digunakan hamper sama. [8] Lingkup pemanfaatan luas. Selain tersebut di atas, dapat juga dipakai untuk membuat film pendek atau kartun, presentasi, iklan atau web banner, animasi logo, control navigasi dan lainlain.

3) Ada alternatif lain selain menggunakan penilaian konvensional jika bukan dengan penilaian berbasis macromedia flash yaitu dengan media visual. Cara mengevaluasi pembelajaran volume kubus dan balok dengan instrumen penilaian yang baik menurut guru kelas adalah dengan menggunakan tes tertulis.

4) Menurut guru kelas, lebih menarik

mengimplementasikan instrumen penilaian berbasis Macromedia flash dibandingkan

menggunakan penilaian konvensional. Pendapat guru kelas tersebut relevan dengan penelitian yang dilakukan oleh Aziz, Kustiono, dan Lestari (2019) tentang kebutuhan analisis untuk pengembangan instrumen penilaian volume kubus dan balok 
berbasis macromedia flash dalam pembelajaran matematika dasar. Penelitian tersebut dilatarbelakangi oleh adanya kesulitan yang dialami guru dalam mengevaluasi

pembelajaran, sehingga ditemukan potensi kolaborasi antar siswa dalam evaluasi. Disamping itu, instrumen yang digunakan oleh guru masih menggunakan instrumen penilaian klasik. Hasil penilaian tersebut diperoleh dari analisis kebutuhan instrumen penilaian volume kubus dan balok berbasis macromedia flash dalam pembelajaran matematika sekolah dasar melalui perhitungan validitas diperoleh Mean Square 0,956 dan dinyatakan sah, serta melalui uji reliabilitas diperoleh 0,414 sehingga dinyatakan handal, maka analisis kebutuhan pengembangan instrumen volume kubus dan balok berbasis macromedia flash dinyatakan valid dan reliable dan sangat dibutuhkan dalam pembelajaran.

5) Saran implementasi instrumen penilaian berbasis Macromedia flash dalam evaluasi pembelajaran volume kubus dan balok di Kelas V dari guru kelas yaitu supaya aplikasi lebih dikembangkan karena belum bisa memunculkan hasil rekap nilai satu kelas. Saran yang diberikan dari guru dalam penelitian menunjukkan bahwa instrumen penilaian berbasis macromedia flash yang digunakan dalam evaluasi pembelajaran volume kubus dan balok mempunyai banyak kekurangan dalam pemanfaatannya secara umum. Hal ini menunjukkan instrumen penilaian agar memperhatikan langkahlangkah proses pengembangan, penyajian, dan pemanfaatan evaluasi belajar secara umum yaitu: [1] Penentuan Tujuan Evaluasi [2] Penyusunan Kisi-Kisi Soal [3] Telaah (Review) dan Revisi Soal, diantaranya terdapat $\mathrm{Uji}$ coba (Try Out), Penyusunan Soal, Penyajian Tes, Scoring, Pengelolaan Hasil Tes, Pelaporan Hasil Tes, dan Pemanfaatan Hasil Tes (Putra, 2013).

6) Guru kelas memilih menggunakan penilaian macromedia flash dalam evaluasi pembelajaran volume kubus dan balok karena siswa lebih paham dengan materi pembelajaran volume kubus dan balok. Pendapat tersebut relevan dengan 


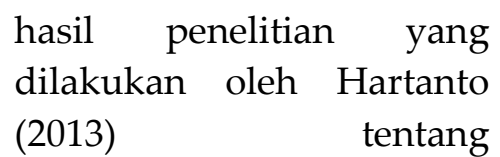
pembelajaran matematika materi bangun ruang balok dengan aplikasi multimedia interaktif di SD Negeri Teguhan Sragen. Penelitian tersebut dilatarbelakangi oleh adanya minat belajar siswa yang rendah, khususnya pada materi bangun ruang. Rendahnya minat belajar tersebut dianggapnya

memungkinkan akan menghasilkan hasil belajar yang tidak maksimal. Disamping itu, rendahnya minat belajar siswa juga dianggapnya dipengaruhi oleh cara penyampaian yang dilakukan guru masih menggunakan system pengajaran konvensional ceramah. Dalam penelitiannya, diterapkan aplikasi Multimedia Interaktif untuk memberbaiki minat belajar siswa. Hasil penelitian tersebut menyimpulkan bahwa siswa merasa tertarik sehingga timbul minat belajar yang lebih baik, melalui penerapan aplikasi tersebut terbukti dapat mempermudah siswa dalam memahami materi pelajaran matematika pokok bahasan bangun ruang balok, dan dengan menggunakan media pembelajaran multimedia interaktif tersebut guru merasa lebih mudah dalam menyampaikan materi pelajaran matematika pokok bahasan bangun ruang balok.

7) Pendapat guru kelas mengenai pengaruh dari implementasi instrumen penilaian berbasis Macromedia flash dalam evaluasi pembelajaran volume kubus dan balok yaitu peserta didik yang lain kurang fokus dalam mengerjakan evaluasi pembelajaran volume kubus dan balok. Hal ini menjadikan pengaruh yang timbul secara langsung sesuai situasi sosial penelitian yang sedang dilakukan.

8) Berkaitan dengan implementasi instrumen penilaian berbasis Macromedia flash dalam evaluasi pembelajaran volume kubus dan balok, belum ada orang lain yang lebih tahu mengenai pengaruh implementasi penilaian berbasis macromedia flash di SDN Depok 01.

9) Guru kelas yakin jika Kurikulum berfokus pada IT dapat memperbaiki belajar mengajar khususnya dalam evaluasi pembelajaran volume kubus dan balok, sebagaimana Suprani \& Hendracipta menyimpulkan bahwa, Macromedia flash is software 
that is easy to use trhough and action script program that is interesting, fast, and easy for someone who does not have qualified knowledge in the field of Information Technology. Dari kesimpulan di atas, diketahui bahwa Macromedia flash merupakan perangkat yang selain mudah dalam mengoperasikannya, juga mempunyai daya tarik yang besar jika memiliki pengetahuan yang memadai dalam teknolog informasi, sehingga jika mampu

mengoperasikannya akan membuat guru atau siswa mengoptimalkan

pelaksanaan evaluasi pembelajaran dan memperoleh hasil nilai yang lebih baik pula.

10) Mengenai implementasi instrumen penilaian berbasis Macromedia flash dalam evaluasi pembelajaran volume kubus dan balok di Kelas V SDN Depok 01 beserta pengaruhnya, Guru kelas menambahkan informasi dalam penyampaiannya bahwa selama ini yang beliau dapatkan adalah aplikasi penilaian rapor, akan tetapi belum pernah mendapatkan sosialisasi penerapan instrumen per mata pelajaran.

\section{Hasil Implementasi Instrumen} Penilaian Berbasis Macromedia flash Dalam Evaluasi Pembelajaran Volume Kubus dan Balok

Implementasi diketahui dari hasil catatan lapangan yang didapatkan selama proses evaluasi pembelajaran volume kubus dan balok menggunakan instrumen penilaian berbasis macromedia flash dilaksanakan. Diketahui terdapat pengaruh dari guru, siswa, dan sekolah.

\section{a. Aspek dari Guru}

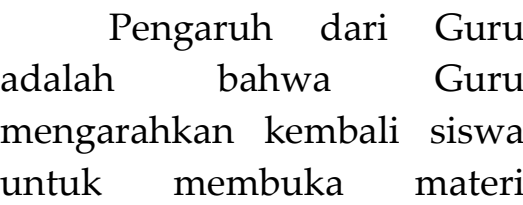
dengan tujuan mengondisikan keadaan kelas agar tetap kondusif ketika terdapat salah satu temannya yang melaksanakan evaluasi pembelajaran volume kubus dan balok berbasis macromedia flash di depan kelas. Selain itu, cara lain dalam mengondisikan kelas yaitu guru juga memberikan reward yang akan diberikan kepada 2 siswanya yang memperoleh skor tertinggi. Skor tertinggi diperoleh AM dan EA. Hal itu dilakukan dalam pelaksanaan evaluasi pembelajaran, supaya anak tidak hilang kefokusan melakukan evaluasi belajar dan tetap membuka materi yang telah diberikan sebagaimana Basrowi \& Siskaridar mengemukakan bahwa evaluasi belajar memiliki dua makna, yakni sebagai ilmu dan seni. Pertama, evaluasi belajar dikatakan sebagai ilmu 
karena evaluasi pembelajaran memenuhi sebagai syarat ilmu pengetahuan. Kedua, evaluasi belajar dikatakan sebagai seni karena dapat dilakukan dengan berbagai cara, metode, strategi, dan alat tes (instrumen). Dari pernyataan tersebut dapat dilihat bahwa evaluasi pembelajaran akan menjadi ilmu pengetahuan yang baik apabila guru sebagai evaluator dapat memainkan cara, metode, strategi, dan instrumen berdasarkan situasi kelas dan kondisi peserta didiknya.

b. Aspek dari Siswa

Pengaruh dari Siswa adalah bahwa siswa gerogi, belum belajar, dan menggunakan laptop untuk pertama kalinya dalam evaluasi pembelajaran volume kubus dan balok. Sehingga ketika siswa memasukkan namanya dalam instrumen penilaian berbasis macromedia flash memakan waktu yang lama pula karena belum terbiasa.

c. Aspek dari Sekolah

Pengaruh dari Sekolah adalah bahwa SD Negeri Depok 01 merupakan sekolah yang tidak ada mata pelajaran Mulok (Muatan Lokal) TIK, melainkan menggunakan Muatan Lokal Tata Boga. Pengaruh yang terjadi karena adanya hubungan erat tiga komponen yang ada di sekolah yaitu tujuan pembelajaran, kegiatan pembelajaran atau KBM, sebagaimana Basrowi (2012) dari uraian Nurkanca, dkk (1986) yang mengemukakan bahwa yang dijadikannya prinsip triangulasi, yaitu adanya hubungan erat tiga komponen diantaranya adalah tujuan pembelajaran, kegiatan pembelajaran atau KBM, dan evaluasi. Dari prinsip tersebut memberi gambaran bahwa tujuan pembelajaran, kegiatan pembelajaran, dan evaluasi adalah satu kesatuan utuh yang tidak dapat dipisahkan, maka sebelum melakukan evaluasi, guru diharapkan menguasai keadaan dan kondisi belajar siswanya.

Dari adanya hubungan erat tiga komponen tersebut maka menjadi hal wajar jika di Sekolah Dasar Negeri Depok 01 kurang baik dalam menggunakan instrumen penilaian berbasis macromedia flash dalam evaluasi pembelajaran volume kubus dan balok di kelas $\mathrm{V}$.

\section{SIMPULAN}

Pelaksanaaan implementasi instrumen penilaian berbasis macromedia flash dalam evaluasi pembelajaran volume kubus dan balok yang dilakukan guru dan siswa di kelas V SDN Depok 01 berjalan sangat baik. Dalam mengimplementasikan instrumen penilaian berbasis macromedia flash pembelajaran volume kubus dan balok di SDN Depok 01 berakibat kurang baik dalam memenuhi syarat alat evaluasi yang baik. Beragam pendapat dari guru kelas V SDN Depok 01 sesuai dengan teori mengenai pelaksanaan implementasi instrumen penilaian berbasis macromedia 
flash dalam evaluasi pembelajaran volume kubus dan balok.

Hasil Implementasi instrumen penilaian berbasis macromedia flash dalam evaluasi pembelajaran volume kubus dan balok di Kelas V SDN Depok 01 dapat diketahui berdasarkan aspek dari guru, siswa, dan sekolah sesuai situasi sosial penelitian.

\section{DAFTAR PUSTAKA}

Al fatah, S.M., Jupriyanto, \& Cahyaningtyas, A.P. (2019). "Analisis Media Pembelajaran Multimedia Interaktif Terhadap Motivasi Belajar Peserta Didik di Sekolah Dasar". Jurnal Pesona Dasar. 7, (2), 18-25.

Andrijati, N. (2014). “Penerapan Media Pembelajaran Inovatif Dalam Pembelajaran Matematika Sekolah Dasar di PGSD UPP Tegal". Jurnal Penelitian Pendidikan. 31, (2), 123-132.

Asmara, A.S. dan Suparman, T. (2018). "Trend Evaluasi dalam Pendidikan Matematika". Jurnal Sekolah Dasar: Elementary School Journal. 1, (3), 8489.

Aziz, K., Kustiono, dan Lestari, W. (2019). "Need Analysis for Development of a Cube and Beam Volume Assessment Instrument in Macromedia flash Based Elementary Mathematics Learning". Journal of Education Research and Evaluation. 8, (2), 99-107.

Dwilestari, S., Robandi, B., dan Fitriani, A.D. (2017). "Penerapan Model Guided Discovery Learning untuk Meningkatkan Pemahaman Konsep Matematika Siswa Kelas V Sekolah
Dasar". Jurnal Pendidikan Guru Sekolah Dasar. 2, (4), 30-41.

Fajarianto, O. dan Wirawa, R. (2013). "Aplikasi Alat Bantu Mengajar Matematika Menggunakan Adobe Flash CS6". Jurnal Sisfotek Global. 3, (2), 13-22.

Hartanto, A. (2013). "Pembelajaran Matematika Materi Bangun Ruang Balok Dengan Aplikasi Multimedia Interaktif di SD Negeri Teguhan Sragen". Seminar Riset Unggulan Nasional Informatika dan Komputer FTI UNSA 2013. 2, (1), 85-89.

Ismiyanti, Y. (2018). "Pengaruh Minat dan Kedisiplinan Terhadap Nilai UAS IPS di SDN 02 Temulus. Jurnal Ilmiah Pendidikan Dasar. 5, (1), 34-43.

Kasih, P.A. dan Purnomo, Y.P. (2016). "Peningkatan Hasil Belajar Matematika Siswa Sekolah Dasar Melalui Pembelajaran Berbasis Penilaian". Journal of Research and Advances in Mathematics Education. 1, (1), 69-78.

Mashudi. (2016). “Penerapan Pendekatan Realistik Untuk Meningkatkan Hasil Belajar Siswa Kelas V Pada Mata Pelajaran Matematika Pokok Bahasan Sifat-Sifat Bangun Ruang". Jurnal Pendidikan Sekolah Dasar. 2, (1), 50-63.

Nurjanah, I., Kusumadewi, R.K., \& Ulia, N. (2019). “Kemampuan Berfikir Kritis Matematis Siswa dengan Menggunakan Model Collaborative Learning dengan Pendekatan OpenEnded Berbantuan Media Macroflash 8". Journal of Mathematics 
and Mathematics Education. 1, (1), 4147.

Pratidiana, D dan Rifa'i, R. (2019). “Penerapan Multimedia Macromedia flash Terhadap Perkembangan Persepsi Visual Siswa Pada Pembelajaran Matematika". Journal Of Matematics Learning. 2, (1), 11-17.

Rahayu, S., \& Hidayati, W.N. (2018). "Meningkatkan Hasil Belajar Matematika Melalui Penggunaan Media Bangun Ruang dan Bangun Datar Pada Siswa Kelas V SDN Jomin Barat I Kecamatan Kotabaru Kabupaten Karawang". Jurnal Pendidikan Sekolah Dasar. 4, (2), 204215.

Sagita, L. \& Kusumarini, A.R. (2017). "Visualization on triangle concept using Adobe Flash Professional SC6". Journal of Physics: Conf. Series 943. 1-7

Setiadi, H. (2016). “Pelaksanaan Penilaian Pada Kurikulum 2013". Jurnal Penelitian dan Evaluasi Pendidikan. 20, (2), 166-178.

Sugiyono. (2017). Metode Penelitian Pendidikan (Pendekatan Kuantitatif, Kualitatif dan RED). Bandung: Alfabeta.

Suprani, \& Hendracipta, N. (2019). "Development Of Character Eduction In Elementary School Through Macromedia flash Fokflore". Jurnal Pendidikan Sekolah Dasar. 5, (2), 180192.

Zainil, M. et al. (2018). "Mathematics learning through Pendidikan Matematika Realistik Indonesia (PMRI) approach and Adobe Flash CS6".
Journal of Physics: Conf. Series 1088. 15. 